\title{
ECOLOGICAL AND ENVIRONMENTAL EDUCATION AS A PART OF THE SUSTAINABLE DEVELOPMENT
}

\author{
[EKOLOGICKA A ENVIRONMENTALNA VYCHOVA AKO \\ SUCAST K UDRZATELNEMU ROZVOJU]
}

\author{
Timea Seben Zatkova - Patricia Marinicova
}

doi: 10.18355/PG.2018.7.1.3

\begin{abstract}
The study deals with the environmental education as a part of sustainable development education. Sustainable development is understood as the development that maintains the possibility to satisfy basic life needs for today and future generations without decreasing of nature diversity in order to maintain natural ecosystem functions. The environmental education means an individual's education whose system of values enables him/her to act wisely and sensitively with respect to protection and maintenance of the life diversity in all its forms. The aim was to review and compare the attitudes of teachers to selected aspects of the realization of the environmental education as a part of sustainability development education in primary schools in towns and villages and in a secondary school in the town of Nitra.
\end{abstract}

\section{Key words}

sustainable development, ecological and environmental education, questionnaire survey

\begin{abstract}
Anotácia
Štúdia pojednáva o environmentálnej výchove ako súčast' výchovy $\mathrm{k}$ trvalo udržatel'nému rozvoju. Pod pojmom udržatel'ný rozvoj rozumieme rozvoj, ktorý súčasným i budúcim generáciám zachováva možnost’ uspokojovat' ich základné životné potreby a pritom neznižuje rozmanitost' prírody a zachováva prirodzené funkcie ekosystémov. Pod pojmom environmentálna výchova rozumieme výchovu jedinca, ktorého hodnotový systém mu umožní múdro a citlivo konat' $\mathrm{v}$ prospech ochrany a zachovania biodiverzity života vo všetkých jeho formách. Ciel'om bolo zistit' a porovnat' názory učitel'ov na vybrané aspekty týkajúce sa realizácie environmentálnej výchovy ako súčast' výchovy $\mathrm{k}$ udržatel’nému rozvoju na základnej škole $\mathrm{v}$ meste a na vidieku a na strednej škole v meste Nitra.
\end{abstract}

\section{Kl’účové slová}

udržatel'ný rozvoj, ekologická a environmentálna výchova, dotazníkový prieskum

\section{Úvod}

Výchova $\mathrm{k}$ udržatel'nému rozvoju je $\mathrm{v}$ súčasnosti rozvíjajúcou sa a vel'mi aktuálnou problematikou vo výchovno-vzdelávacom procese vzhl'adom na aktuálne meniace sa spoločenské a prírodné podmienky. Na tieto naznačené 
zložitosti a problémy celosvetového vývoja sa usilujú hl'adat' odpovede, riešenia a konkrétne prostriedky niektoré vzdelávacie aktivity, projekty a produkty, ako sú humanitárne vzdelávanie, vzdelávanie pre udržatel'ný rozvoj, rozvojové vzdelávanie, globálne vzdelávanie, svetová edukácia, svetová orientácia a podobne. Aj ked' uvedené koncepty by sme mohli všeobecne chápat' ako synonymá, každé z nich obsahuje istú významovú špecifickost'. Zámerom tejto štúdie je však aj z hl'adiska obmedzeného rozsahu nášho textu venovat' sa najmä niektorým realizačným aspektom ekologickej a environmentálnej výchovy, ktorá je súčast’ou výchovy k udržatel'nému rozvoju.

Pojmy udržatel'nost' (sustainability) a udržatel'ný rozvoj (sustainable development) sa začali používat' začiatkom 70-tych rokov najmä v súvislosti s poznaním, že nekontrolovatel'ný rast akýkol’vek (populácie, výroby, spotreby, znečistenia a pod.) je neudržatel'ný v prostredí obmedzených zdrojov (Národná stratégia trvalo udržatel'ného rozvoja SR, 2001). Aj ked' v slovenskom prostredí sa v starších dokumentoch používa označenie ,trvalo udržatel'ný rozvoj“, odporúčame dodržat' presný preklad z anglického jazyka „sustainable development“, čo znamená „udržatel'ný rozvoj“. Na základe nejednotnej terminológie v cudzojazyčnom prostredí a v slovenskej proveniencii budeme pre účely tejto štúdie uplatňovat' obe označenia ako synonymá aj ked' samozrejme ,trvalé“ nie je nič, ked’že všetko v našom svete podlieha zmenám a neustálemu vývoju.

Udržatel'ný rozvoj v Slovenskej republike právne vymedzuje $§ 6$ zákona č. 17/1992 Zb. o životnom prostredí. Podl'a neho ide o taký "rozvoj, ktorý súčasným i budúcim generáciám zachováva možnost' uspokojovat' ich základné životné potreby a pritom neznižuje rozmanitost' prírody a zachováva prirodzené funkcie ekosystémov."

Pojem trvalo udržatel'ný rozvoj (d'alej len TUR) obsahuje dva termíny: trvalo udržatel'ný, ktorý označuje určité obmedzenia čo predstavuje takú skutočnost', že zdroje sa majú využívat', ale nie sa vyčerpat'. Rozvoj predstavuje záležitost' hodnôt. Pod týmto pojmom nerozumieme len rast ekonomický, ale aj rozvoj všetkého od čoho závisí kvalita života, ktorá v sebe zahŕňa rozvoj vzdelávania, sociálnych služieb, starostlivosti o zdravie, kultúry, l'udských práv či politickej slobody a iné. Ked' hovoríme o rozvoji ako takom nemožno opomenút', že do tejto kategórie patrí aj zvel'ad'ovanie ochrany prírody a životného prostredia (Nové trendy v ekológií, 2000).

Udržatel'ný rozvoj by mal byt' predovšetkým ekologický. Život nad rámec únosnej kapacity planéty nie je možný TUR pozostáva z ekonomickej a sociálnej oblasti, pričom obe sú závislé na environmentálnom zdraví (Simonovicova, Koskova, 2011).

TUR je definovaný ako cielený, dlhodobý a komplexný proces ovplyvňujúci všetky oblasti života (sociálna, inštitucionálna, environmentálna, duchovná, ekonomická), ktorý prebieha na viacerých úrovniach (miestnej, regionálnej, národnej, medzinárodnej) a smeruje k presadzovaniu praktických nástrojov a inštitúcií $\mathrm{k}$ takému modelu fungovania spoločnosti, ktorý uspokojuje potreby l'udstva a zároveň akceptuje hodnotu prírody a neprekračuje hranice únosnej kapacity prírody (Národná stratégia trvalo udržatel'ného rozvoja SR, 2001). V súlade s Národnou stratégiou (2001) sú medzi cesty a prostriedky 
na podporu priorít a dosiahnutia strategických ciel'ov TUR SR zaradené aj posilnenie právneho vedomia, zmena hodnotových orientácií obyvatel'ov, výchova a osveta a vybudovanie moderného a kvalitného školského systému, podpora vedy a výskumu. Prvým rozhodujúcim činitel'om pôsobiacim na formovanie l'udského vedomia sú najmä rodičia, rodina, príbuzní a vychovávatelia. Sú to prevažne neškolení l'udia. Druhým rozhodujúcim činitel'om je škola a hlavne učitel', ktorý by mal žiakov vzdelávat' v intenciách princípov a kritérií TUR. Environmentálne vzdelávanie a výchova by mali byt' $v$ modernej demokratickej spoločnosti samozrejmou súčast'ou školského systému. Priorita by mala byt' kladená na integráciu kultúrnych, prírodných, historických a spoločenských aspektov, zdrojov a potenciálu do jednotlivých vyučovacích predmetov do základného a stredného školstva ako súčast' široko koncipovaného procesu environmentálnej výchovy a vzdelávania. Takúto integráciu je vhodné realizovat' prostredníctvom učebných osnov, rozvojom a aplikáciou praktických zručností a podporou tvorivosti, poznania svojho sociálneho, historického a prírodného prostredia (rodina, domov, obec, región).

\section{Použité metódy}

Ciel'om štúdie je stručne popísat' základné teoretické východiská problematiky a zistit' a porovnat' názory učitel'ov na vybrané aspekty týkajúce sa realizácie environmentálnej výchovy, ktorú ponímame ako súčast' výchovy k udržatel'nému rozvoju na vybraných školách a to na základných školách v meste a na vidieku a na strednej škole v meste Nitra. V prieskume sme využili dotazník vlastnej konštrukcie, ktorý obsahoval 10 položiek a základné identifikačné údaje. Dotazník zahŕňal pät' otvorených otázok, dve otázky boli polouzavreté a tri uzavreté otázky, z toho jedna dichotomická a jedna s jednoduchým výberom. Dotazník sme administrovali v októbri v školskom roku 2016/2017. Prieskumnú vzorku tvorilo na základných školách 8 respondentov zo ZŠ s MŠ Stará Kremnička 33 a ZŠ Pavla Križku v Kremnici. Z oslovených respondentov, traja učitelia učia v neplno organizovanej škole na vidieku a 5 v mestskej základnej škole. Všetci učitelia (respondenti) učia na 1.stupni základnej školy. Na strednej odbornej škole veterinárnej v Nitre sme vybrali vzorku 10 respondentov. Vybraní učitelia učia predmety prírodovedného zamerania. Čiastkové ciele nášho deskriptívneho prieskumu boli zamerané na zistenie názorov učitel'ov na vybrané hl'adiská, ktoré sa týkajú realizácie environmentálnej výchovy a to:

- Zistit' a porovnat' názor učitel'ov na dôležitost' realizácie environmentálnej výchovy.

- Zistit' a porovnat' názory učitel'ov na ich odbornú a metodickú pripravenost' pre realizáciu environmentálnej výchovy.

- Zistit', či učitelia $\mathrm{v}$ posledných piatich rokoch absolvovali školenie $\mathrm{k}$ problematike realizácie environmentálnej výchovy.

- Zistit' a porovnat' názory učitel'ov na materiálne vybavenie škôl pre realizáciu environmentálnej výchovy.

- Zistit' a porovnat', či do environmentálnych aktivít učitelia zapájajú aj rodičov žiakov. 
- Zistit', ktoré témy z environmentálnej výchovy sa najčastejšie realizujú v edukácii oslovenými učitel'mi.

\section{Výsledky: Dokumenty zabezpečujúce výchovu a vzdelávanie k udržatel'nému rozvoju}

Udržatel'ný rozvoj ako globálny rozvojový program pre 21. storočie bol deklarovaný na Konferencii OSN o životnom prostredí a rozvoji v Rio De Janeiro (1992). Základným dokumentom TUR je Deklarácia o životnom prostredí a rozvoji, ktorá vymedzuje 27 zásad (Toma, 2001). Usmernenie ako tieto zásady premietnut' do života reprezentuje AGENDA 21, ktorá sa považuje za prvý celosvetový dokument o uplatňovaní TUR v rôznych sférach na rôznych hierarchických úrovniach (In Kolšovská, 2009). Dokument Národnej stratégie trvalo udržatel'ného rozvoja, bol schválený v roku 2001. Nadväzujúci dokument Akčný plán udržatel'ného rozvoja na roky 2005-2010, už uvádza konkrétne ciele a potreby pre Slovenskú republiku. Samotná príprava akčného plánu prebiehala v gescii Úradu vlády SR, čo možno považovat' za významnú skutočnost' potvrdzujúcu nadrezortný charakter problematiky trvalo udržatel'ného rozvoja (Hilbert, 2007). Samotný akčný plán uvádza 14 prioritných oblastí. Z hl'adiska výchovy a vzdelávania $\mathrm{k}$ udržatel'nému rozvoju odpovedá prioritná oblast' č. 12 „Implementácia základných princípov trvalo udržatel'ného rozvoja do učebných osnov na všetkých stupňoch škôl v SR a v systéme celoživotného vzdelávania“. V tomto smere sa počíta najmä so začlenením Stratégie vzdelávania $\mathrm{k}$ trvalo udržatel'nému rozvoju do vzdelávacieho procesu a $\mathrm{s}$ vypracovaním a schválením novej koncepcie environmentálnej výchovy a vzdelávania (Environmentálnej akadémie) (Kolocany, 2006). Na akčný plán nadväzovala snaha o vypracovanie stratégie výchovy k udržatel'nému rozvoju, zriadenie nadrezortného poradného orgánu pri MŠ SR a MŽP SR s ciel'om plnit' úlohy medzi ktoré patrí inovácia prekonanej koncepcie environmentálnej výchovy a vzdelávania vo všetkých stupňoch škôl SR a v systéme celoživotného vzdelávania, zabezpečovanie filozofie a základných princípov udržatel'ného rozvoja do učebných osnov všetkých škôl SR a systému celoživotného vzdelávania. Nasledovná výzva k vypracovaniu Akčného plánu výchovy k udržatel'nému rozvoju predpokladá paradigmy:

- V rámci výchovy $\mathrm{k}$ udržatel'nému rozvoju environmentálna výchova zabezpečuje aspekt environmentálneho piliera. Aspekt ekonomického a sociálneho piliera tvoria rovnocenné bloky.

- Len prepojenie aspektu environmentálneho, ekonomického a sociálneho a akceptovanie ich holistického prepojenia je možné porozumenie a definovanie výchovy k TUR. Nakol'ko ide o potrebu celej spoločnosti, malo by íst' o celoživotné vzdelávanie.

- V praxi je takto chápaná integrácia, snaha o zapojenie princípov TUR všetkých pilierov.

- Výchova k udržatel'nému rozvoju umožní akceptovat' toto prepojenie v praxi, ktoré podmieňuje obsah a ciel' (profil) vzdelávania k udržatel'nému rozvoju, musí obsahovat' navyše zložku emotívnu, kognitívnu, konatívnu (Hilbert, 2007). 
$\mathrm{V}$ agende OECD sa osobitne jedná o ciele z Environmentálnej stratégie OECD pre prvú dekádu 21. storočia (2001), Environmentálneho výhl'adu OECD do roku 2030 (2008), Stratégie zeleného rastu OECD (2011), Environmentálneho výhl'adu OECD do roku 2050 (2012), ako aj odporúčaní OECD z Prehl'adu o environmentálnej výkonnosti SR (2011). Pre rezortnú koncepciu Environmentálnej výchovy sú klúčové viaceré dokumenty Európskej únie - v rámci Obnovenej stratégie trvalo udržatel'ného rozvoja EÚ (2006) - „Stratégie Európa 2020 na zabezpečenie inteligentného, udržatel'ného a inkluzívneho rastu“ (2010) sa má Slovenská republika ako člen EÚ orientovat' na realizáciu jej piatich hlavných ciel'ov a to v: - rozvoji zamestnanosti; - vzdelávania; - výskumu a inovácie; - sociálneho začlenenia a chudoby; - oblasti klímy a energetiky.

\section{Výchova a vzdelávanie $k$ udržatel'nému rozvoju}

Vzdelávanie okrem toho, že je jedným zo základných l’udských práv, je predpokladom dosiahnutia trvalo udržatel'ného rozvoja a dôležitým nástrojom účinného riadenia, zdôvodneného rozhodovania a rozvoja demokracie. Výchova k udržatel'nému rozvoju rozvíja a posilňuje schopnost' jednotlivcov, skupín, komunít, organizácií a krajín vykonávat' vlastné rozhodnutia a vol'by v prospech trvalo udržatel'ného rozvoja. Môže viest' $\mathrm{k}$ zmene $\mathrm{v}$ názoroch l'udí a tak im umožnit' urobit' tento svet bezpečnejším, zdravším a prosperujúcejším, zvyšujúc tým kvalitu života. Výchova $\mathrm{k}$ trvalo udržatel'nému rozvoju môže zabezpečit' kritické myslenie a zvýšenie informovanosti, ako aj rozšírenie možností a tým umožní vytvorit' nové koncepcie a vyvinút' nové metódy a nástroje (Stratégie európskej hospodárskej komisie OSN pre výchovu k trvalo udržatel'nému rozvoju, 2007).

V roku 2006 bola vypracovaná nová koncepcia environmentálnej výchovy a vzdelávania na všetkých stupňoch škôl v SR a v systéme celoživotného vzdelávania, ktorá bola schválená v júni 2006 ministrom školstva SR. Koncepcia za klúčový faktor environmentálnej výchovy a vzdelávania považuje výchovu a vzdelávanie $\mathrm{k}$ trvalo udržatel'nému rozvoju. Nová koncepcia stanovuje štyri základné priority: (1) prijatie filozofie, ciel’ov a stratégií $\mathrm{k}$ implementácii výchovy $\mathrm{k}$ trvalo udržatel'nému rozvoju, (2) zvýšenie kvality edukácie v oblasti environmentálnej výchovy, (3) inovácia environmentálnej výchovy a (4) rozšírenie Koncepcie environmentálnej výchovy a vzdelávania z r. 1997 o aspekt výchovy $\mathrm{k}$ trvalo udržatel'nému rozvoju (Hilbert, 2007b). Následne bol vypracovaný Akčný plán $\mathrm{k}$ výchove a vzdelávaniu $\mathrm{k}$ trvalo udržatel’nému rozvoju. Jeho snahou je aj premietnutie výchovy a vzdelávania $\mathrm{k}$ TUR do kurikulárnej transformácie. V rámci nej boli navrhnuté nasledovné témy životného prostredia: Prírodné vedy okolo nás, Energia a jej premeny, Proces, zmena, pohyb, Zem a vesmír, Zloženie látok, Komunikácia. Okruhy sú zadefinované vel'mi všeobecne, bližšie sú rozpracované $\mathrm{v}$ rámci učebných osnov a učebných plánov. Ako uvádza Izakovicova (2010) za pozitívum kurikulárnej transformácie možno považovat' aplikáciu nových nástrojov na efektívnu výchovu a vzdelávanie orientácia na život, aplikácia nových progresívnych didaktických metód, zvýšenie kompetencií školám a pod. Na druhej strane podl'a nej táto vol'nost' 
môže spôsobit' vytlačenie environmentálnej výchovy na okraj výchovy a vzdelávania $\mathrm{v}$ tej ktorej škole. Bude to závisiet' vo vel'kej miere od environmentálnej vyspelosti pedagógov.

\section{Výchova a vzdelávanie $k$ udržatel'nému rozvoju na školách}

Hilbert (2007) sa venoval hodnoteniu plnení opatrení a úrovni environmentálnych poznatkov žiakov stredných škôl, ktoré boli vypracované ešte v roku 2000/2001 Štátnou školskou inšpekciou, z uvedeného tak vyplýva nasledovné: Opatrenia Koncepcie sa plnia na priemernej úrovni. Zapracovanie učebných osnov environmentálneho minima do časovo tematických plánov na gymnáziách je na dobrej úrovni, na stredných odborných školách a stredných priemyselných školách len na priemernej úrovni. Ďalšie vzdelávanie pedagogických pracovníkov v environmentálnej oblasti a používanie nových materiálov a učebných pomôcok je na podpriemernej úrovni, mimovyučovacie a mimoškolské aktivity žiakov environmentálneho charakteru sú na priemernej úrovni. Projekt Školy podporujúce zdravie je na školách rozšírený rôzne $\mathrm{s}$ regionálnymi odlišnost’ami. Opatrenia vyplývajúce $\mathrm{z}$ národných konferencií sa plnia na priemernej úrovni. Prevláda priemerná rozpracovanost' koncepcie environmentálnej výchovy na školách, funkcia koordinátora je rozšírená málo, čo spôsobuje, že integrácia a kooperácie v oblasti vyučovania ekológie a environmentalistiky dosahuje iba priemernú úroveň. Úroveň environmentálnych poznatkov možno považovat' za dobrú až priemernú.

$\mathrm{O}$ tri roky neskôr Koncepciu výchovy $\mathrm{k}$ trvalo udržatel'nému rozvoju na Slovensku hodnotia ochranári kriticky: Ros (2004) uvádza, že výchova $\mathrm{k}$ trvalo udržatel'nému rozvoju je predovšetkým o hladaní prepojenia a výchove $\mathrm{k}$ zodpovednosti. Definíciu a podstatu udržatel'ného rozvoja ovláda, len zhruba $10 \%$ učitel’ov, čo je málo. Uvádza, že pojem udržatel'ný rozvoj je v dnešnej dobe heslo, ktorým je možné plátat' všetko.

To či je trvalo udržatel'ný rozvoj tou správnou cestou vo výchove komentuje Hips (2005) nasledovne: „Akonáhle sa budeme viac a viac ekonomicky rozvíjat', tak zákonite budeme potrebovat' viac zdrojov a surovín z našej planéty, produkovat' viac odpadu, emisií... Rečiam o tom, že l'udstvo dokáže zladit' svoj materiálny rozvoj a zároveň chránit' životné prostredie, neverím. Pretože viem, že planéta má svoje hranice a l'udská civilizácia sa nemôže súčasným smerom rozvíjat' d’alej. Alebo môže, ale nie tak, aby bol udržaný život na Zemi."

V roku 2009 boli na základe teoretických i empirických skúseností výsledkom národnej konferencie Výchova a vzdelávanie $\mathrm{k}$ trvalo udržatel'nému rozvoju (2009) formulované nasledovné závery a odporúčania:

- vyjasnit' koexistenciu označenia environmentálna výchova a výchova $\mathrm{k}$ udržatel'nému rozvoju,

- z pohl'adu inštitucionálnych nástrojov V TUR posilnit' úlohu škôl možnost’ou čerpat' finančné prostriedky vyčlenené na výchovu a vzdelávanie k TUR v rezorte MŠ SR,

- implementovat' udržatelný rozvoj plošne do všetkých vyučovaných predmetov a novo zohl'adnit' začleňovanie prierezových tém zaistujúcich komplexné poňatie V TUR;

Slavonic Pedagogical Studies Journal, ISSN 1339-8660, eISSN 1339-9055, Volume 7 Issue 1, February 2018 
- využit' kurikulárnu reformu k dosiahnutiu tohto zámeru; nástrojom realizácie je predovšetkým celoživotné vzdelávanie učitel'ov jednotlivých, ale i príbuzných predmetov,

- posilnit' kl'účovú úlohu riaditel'ov a koordinátorov výchovy k TUR;

- nástrojom $\mathrm{k}$ osvete a manažmentu škôl v oblasti TUR je celoživotné vzdelávanie,

- venovat' viac pozornosti zriad'ovatel'om škôl a uskutočnit' stretnutia ich zástupcov a výmenu skúseností na národnej úrovni aj s prezentovaním dobrých skúseností zo zahraničia.

Možno konštatovat', že $z$ hl'adiska presadzovania TUR na školách je dôležité prehlbovanie demokratizácie a humanizácie vzdelávania, zvýšenie vzdelanostnej úrovne, rozvoj vzdelávacích príležitostí a rovnost' prístupu ku vzdelaniu, zmeny $\mathrm{v}$ riadení, štruktúre a ekonomickom zabezpečení vzdelávacieho systému a zmeny $\mathrm{v}$ obsahu vzdelávania (kurikulárna transformácia). Dôležitá je ekologizácia a environmentalizácia obsahu vzdelávania $\mathrm{v}$ študijných programoch. Je potrebné venovat' zvýšenú pozornost' rozšíreniu predmetov, resp. výučby v oblasti právneho vedomia, l'udských práv, kultúrno-historického vedomia, cudzích jazykov a pod. Výrazne treba rozšírit' rôzne formy celoživotného vzdelávania, vzdelávanie pracovníkov verejnej správy, rozšírit' rôzne formy rekvalifikačných kurzov a pod. Do výchovy a vzdelávania by sa mali dostat' aj nové aktuálne témy, napr. podl'a Národného programu boja proti korupcii (2000) rozšírit' etickú výchovu a občiansku náuku, podl'a Koncepcie environmentálnej výchovy a vzdelávania (Environmentálnej akadémie) environmentalistiku, ktorá teoreticky i prakticky najúčinnejšie vedie k TUR (MZP SR, 2001).

\section{Environmentálna výchova}

V predchádzajúcom texte sme naznačili, že environmentálna výchova rozvíja témy udržatel'ného rozvoja a preto sa d'alej budeme venovat' problematike realizácie environmentálnej výchovy. Viacerí autori (napr. 5. národná konferenciu s medzinárodnou účast’ou Výchova a vzdelávanie k trvalo udržatel'nému rozvoju, 2009) tiež upozorňujú na nevyjasnenost' terminologických vzt’ahov medzi environmentálnou výchovou a výchovou $\mathrm{k}$ trvalo udržatel'nému rozvoju (udržatel'nému rozvoju), čo môže komplikovat' d'alšie teoretické rozpracovanie a praktické aplikovanie danej problematiky do praxe.

Environmentálna výchova vznikla ako odpoved' na potreby doby a jej obsah sa postupne vyvíjal na základe meniacej sa spoločenskej a kultúrnej situácie, čomu odpovedali aj názory (Horka, 2005).

Vývoju environmentálnej výchovy predchádzalo množstvo medzinárodných stretnutí a konferencií s podobnou myšlienkou. V roku 1968 sa v Paríži uskutočnila prvá konferencia UNESCO s ciel'om vývoja učebných osnov pre všetky stupne vzdelávania a zvyšovania povedomia o globálnych problémoch životného prostredia. Na d'alšej konferencii UNESCO v Nevade roku 1970 bola formulovaná definícia environmentálnej výchovy ako proces poznávania hodnôt a objasnenia pojmov s ciel'om rozvíjat' zručnosti a postoje potrebné $\mathrm{k}$ pochopeniu vzájomných vzt’ahov medzi človekom a životným prostredím a v 
praktických situáciách robit' správne rozhodnutia o problémoch týkajúcich sa kvality životného prostredia (Biedenweg et al., 2013).

Z časového hl'adiska môžeme environmentálnu výchovu definovat' ako systematický globálny proces formovania jednotlivca od útleho detstva až do dospelosti, rozvíjajúci jeho sebaúctu, sebadôveru, i úctu a dôveru voči iným ako základ skupinovej kooperácie a zodpovednosti. Tento proces je budovaný na aktívnom subjektívnom vzt’ahu osobnosti k životnému prostrediu. Výsledkom procesu je jedinec citlivý, rozumný, zodpovedný k vonkajšiemu prostrediu, tolerantný ku všetkým živým organizmom a ostatným l'ud'om a schopný vytvárat' vlastný spôsob života, životný štýl (Nanistova, Mesarosova, 1993; Hilbert, 1996).

Osobná skúsenost' a schopnost' riešit' problémy, ktoré sú základom environmentálnej výchovy, pomáhajú rozvíjat' kritické myslenie a zručnosti, ktoré sú predpokladom k rozvíjaniu etického prístupu k svetu (Stevenson et al., 2013).

Existuje mnoho pohl'adov a definícií environmentálnej výchovy, ktorú je možné chápat' aj ako ,výchovu jedinca, ktorého hodnotový systém mu umožní múdro a citlivo konat'v prospech ochrany a zachovania biodiverzity života vo všetkých jeho formách, ktorý bude schopný súcitu s prírodou a inými živými tvormi a ktorý bude ochotný preberat' zodpovednost' za svoje konanie a prijímat' dobrovol'nú skromnost' ako spôsob života únosne zat'ažujúc životné prostredie." (Vincikova, 1998).

Každý človek môže pomôct' svojím ekologicky zodpovedným prístupom v bežných činnostiach $\mathrm{k}$ zlepšeniu životného prostredia. Vždy je dôležité vediet', prečo a za akým účelom danú činnost' vykonávame. Na medzinárodnej konferencii o environmentálnej výchove a vzdelávaní $\mathrm{v}$ Tbilisi v roku 1977 boli prijaté nasledovné ciele (Zedginidze, Chanturia, Siprashvili, 2012):

- Posilnit' uvedomenie si vzájomnej závislosti ekonomickej, sociálnej, politickej a ekologickej sféry v mestských a vidieckych oblastiach.

- Každému poskytnút' príležitost' nadobudnút' vedomosti, hodnoty, postoje, záväzky, a zručnosti potrebné na ochranu životného prostredia.

- Vytvorit' nové vzory správania jednotlivcov, skupín a spoločnosti ako celku, ústretové k životnému prostrediu.

\section{Environmentálna výchova vo formálnom vzdelávaní}

Environmentálna výchova (d’alej EVV) vo formálnom vzdelávaní sa chápe ako organická súčast' celého komplexu výchovy a vzdelávania na základných a stredných školách. Na jej realizáciu v základných a stredných školách boli vypracované nadpredmetové učebné osnovy environmentálne minimum. Ciel'om EVV v základnej a strednej škole je formovat' a rozvíjat' osobnostné kvality, ktoré usmernia žiakov chránit' a zlepšovat' životné prostredie ako dlhodobý zámer výchovnej práce na základných školách a na všetkých druhoch stredných škôl. Učebné osnovy nestanovujú konkrétne výchovné ciele v jednotlivých témach (Hilbert, 2007a).

Na stredných odborných školách sa pripravujú aj odborníci - stredoškolsky vzdelaní ekológovia v študijných odboroch (lesníctvo, krajinná ekológia, analytická chémia- monitorovanie kvality ŽP, chemická technológia- sanácia 
ŽP ako príklady). Na stredných odborných školách sa pripravujú žiaci $\mathrm{v}$ študijných odboroch operátor ekologických zariadení, chemik operátor so zameraním na životné prostredie. Na stredných školách sa využívajú rôzne metódy a formy práce, napr. projektové vyučovanie, problémové vyučovanie, inscenácia modelových situácií, $\mathrm{V}$ rámci praktických cvičení niektoré školy si vo svojom okolí vytvorili náučné chodníky (Hilbert, 2007a).

Environmentálna výchova smeruje $\mathrm{k}$ dokonalej harmónii cítenia, myslenia a je najvýznamnejším etickým nástrojom ochrany životného prostredia. Environmentálna výchova by nemala byt' chápaná ako nadradená k ostatným zložkám výchovy, ale ako prostriedok vnášajúci do výchovy novú filozofiu filozofiu udržatel'ného rozvoja jednotlivca, spoločnosti a celej planéty (Pagac, 1993; Kopp, 2008).

Formálna EVV sa na Slovensku sústred'uje v zariadeniach školského typu. Je zastrešená $\mathrm{v}$ Štátnom vzdelávacom programe od kategórie predprimárneho vzdelávania až po stredné odborné vzdelanie. Vo všetkých stupňoch vzdelávania je definovaná ako prierezová téma spadajúca pod príslušné vzdelávacie oblasti. Školské zariadenia na všetkých stupňoch vo všeobecnosti plnia obsah environmentálnej výchovy realizovaním rôznorodých aktivít a projektov. Komplexnejšie k problematike pristupujú tie, ktoré prezentujú environmentálne zameranie a ciele vo svojich školských vzdelávacích programoch a boli zapojené do projektov dlhodobého charakteru. $\mathrm{K}$ týmto záverom $\mathrm{v}$ kategórii predprimárneho vzdelávania dospela aj Štátna školská inšpekcia (ŠS̆I), závery prezentovala vo svojej správe Správa o environmentálnej výchove v materských školách $\mathrm{v}$ školskom roku 2012/2013 v SR. Formálnu EVV koordinuje Ministerstvo školstva, vedy, výskumu a športu Slovenskej republiky (MŠVVaŠ SR). Opodstatnené sú preto odporúčania pre užšiu spoluprácu medzi MŽP SR a MŠVVaŠ SR pri tvorbe učebných osnov. Z tohto dôvodu je dôležité zadefinovat' zo strany MŽP SR potrebné oblasti vzdelávania $\mathrm{v}$ oblasti starostlivosti o životné prostredie. Rovnako dôležitá je aj vzájomná spolupráca pri tvorbe publikácií a pri aktivitách zameraných na oblast' formálnej environmentálnej výchovy. V prípade prekategorizovania environmentálnej výchovy z prierezovej témy na vzdelávaciu oblast', spolu s dopracovaním učebných osnov a publikácií, by sa $\mathrm{v}$ budúcnosti mohli dosiahnut' lepšie výsledky jej uplatňovania v praxi. (Rezortná koncepcia environmentálnej výchovy, 2015).

\section{Hodnotenie realizácie environmentálnej výchovy na vybraných školách $\mathrm{z}$ pohl'adu učitel'ov}

Empirické výsledky sme získali na základe vyhodnotenia dotazníkov na základných školách v meste a na vidieku, kde všetci oslovení respondenti boli ženy vo veku od 45 až 59 rokov. Dotazník na strednej odbornej škole veterinárnej v Nitre vyplnilo 10 respondentov, z toho 5 žien vo veku $40-61$ rokov a 5 mužov vo veku $32-60$ rokov. Zameranie učitel'ov, ktorí vypracovali dotazník bolo predovšetkým prírodovedné (predmety Biológia Telesná výchova, Biológia - Matematika, Matematika - Chémia) a odborné predmety (veterinárne predmety a predmety živočíšnej výroby).

V otázke č. 1 dotazníka, 37,5 \% z oslovených respondentov jednoznačne uviedli, že realizácia environmentálnej výchovy na základnej škole je vel’mi 
dôležitá. Ostatní $(62,5 \%)$ dôležitost' uviedli ako nevyhnutnost' učit' deti $\mathrm{k}$ vzt’ahu k prírode a prostrediu v ktorom žijú, ako potrebu vychovávat' deti $\mathrm{k}$ hodnotám, či realizovat' environmentálnu výchovu $\mathrm{v}$ rámci medzipredmetových vzt’ahov $\mathrm{v}$ celom vyučovacom procese. Zásadné rozdiely $\mathrm{v}$ názoroch na dôležitost' realizácie environmentálnej výchovy u učitel'ov sa nevyskytovali. Všetci $(100 \%)$ opýtaní vo svojich odpovediach uviedli, že realizácia EVV má svoje miesto vo vyučovacom procese. $\mathrm{Na}$ strednej škole tiež odpovedali všetci respondenti, že dôležitost' realizácie environmentálnej výchovy na strednej škole je nesmierne dôležitá. Jednotlivo respondenti uviedli, že: „environmentálnej výchove by sa mala venovat väčšia pozornost', aby žiaci pochopili, aký význam má starostlivost' o životné prostredie a prírodu; EVV vedie človeka k pochopeniu vztahov medzi organizmami a uči človeka, aby si vytvoril vztah $k$ životnému prostrediu; EVV by mala byt' súčastou života každého človeka od škôlky, na strednej škole je nevyhnutná, pretože medzipredmetové vztahy umožn̆ujú spájat' informácie, ktoré vedú k premyslenej a cielavedomej ochrane životného prostredia; EVV je dôležitá aby dorastajúca generácia vplývala na zlepšovanie životného prostredia“.

Pri položke akým podielom by sa mala zúčastňovat' školská EVV v pomere $\mathrm{k}$ rodinnej environmentálnej výchove sme zistili nasledovné: $50 \%$ opýtaných je toho názoru, že škola by sa mala podiel'at' $70 \%$-tami na realizácii environmentálnej výchovy. Názor, že podiel výchovy v škole a rodine by mal byt' rovnaký zastáva $12,5 \%$ respondentov. Prevažná väčšina dopytovaných $(87,5 \%)$ uvádza, že škola by mala realizovat' a implementovat' environmentálnu výchovu vo viac ako $50 \% \mathrm{v}$ pomere $\mathrm{s}$ výchovou $\mathrm{v}$ rodine. $\mathrm{Z}$ uvedeného možno predpokladat', že učitelia zastávajú názor, že žiak $\mathrm{v}$ domácom prostredí, nie je dostatočne vedený a vychovávaný $\mathrm{k}$ vzt’ahu k prírode a životnému prostrediu. Suchá (2014) vo svojom výskume zameranom na aktuálny stav mimoškolskej environmentálnej výchovy na Slovensku uvádza, že takmer každé diet’a sa narodí do rodiny (či už úplnej, alebo neúplnej) a práve $\mathrm{v}$ nej získa vstupné predpoklady pre jeho následný vývoj. Pozitívne hodnoty a pozitívny vzt'ah k prírode a okolitému prostrediu je potrebné u dietat'a rozvíjat' od útleho detstva. V ranných detských obdobiach sú príkladom a vzorom správania sa $\mathrm{k}$ okolitému prostrediu rodičia. Práve rodičia dávajú mnohokrát rozhodujúci impulz vztahu k prírode. Oni dokážu u diet'at’a podchytit' záujem a lásku k okolitému prostrediu, $\mathrm{k}$ jeho ochrane i k jeho rozvoju. (Martisova, 2012). Odpovede respondentov strednej školy obsahovali názor, že škola by sa mala podiel'at' na environmentálnej výchove $\mathrm{v}$ rozmedzí jednotlivých odpovedí od $50 \%$ až po $90 \%$ podiel výchovy v porovnaní $\mathrm{s}$ EVV v rodine. V sumáre názory všetkých učitel'ov z hl'adiska podielu realizácie environmentálnej výchovy $\mathrm{v}$ škole a v rodine sú $\mathrm{v}$ približne rovnakom pomere, súhrnne sa vo všetkých odpovediach vyskytovalo rozpätie od $50 \%$ podielu vyššie.

Položky 3 a 6 boli zamerané na zistenie absolvovania školení, seminárov resp. iných druhov vzdelávania $\mathrm{k}$ problematike environmentálnej výchovy. $75 \%$ opýtaných respondentov základných škôl odpovedalo, že v posledných piatich rokoch neabsolvovali žiadne školenie, seminár či vzdelávanie Dvaja učitelia $(25 \%)$ sa takéhoto vzdelávania zúčastnili. Pričom jeden učitel' pôsobí

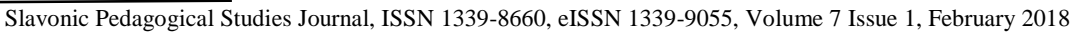


v mestskej škole a jeden v neplnoorganizovaj škole na vidieku. V rámci dotazníka bolo ciel'om zistit' aj $\mathrm{v}$ akých organizáciách títo učitelia vzdelávanie absolvovali. Boli uvedené dve: a to organizácia Živica a Strom života. Ani jeden z opýtaných stredoškolských učitel'ov neabsolvoval v priebehu posledných 5 rokov školenie, seminár, resp. vzdelávanie k problematike realizácie environmentálnej výchovy.

V položke č. 4 sme zist'ovali akým spôsobom sa na školách realizuje environmentálna výchova. $50 \%$ respondentov uviedlo, že ich škola je environmentálne zameraná, 37,5\% odpovedalo, že environmentálna výchova sa realizuje na škole ako prierezová téma a $12,5 \%$ odpovedalo, že základná škola nevenuje osobitnú pozornost' realizácii environmentálnej výchovy. Pokial' by sme chceli hodnotit' rozdiely medzi mestskou a vidieckou školou, môžeme konštatovat', že 80 \% učitel'ov mestskej školy hodnotilo, že ich škola je environmentálne zameraná a $20 \%$ uviedlo, že ENV realizujú ako prierezovú tému. V základnej škole na vidieku $67 \%$ učitel'ov odpovedalo, že ENV realizujú ako prierezovú tému a $33 \%$ uviedlo, že environmentálnej výchove v škole nevenujú osobitnú pozornost'. Stredoškolskí učitelia uviedli, že až $70 \%$ realizuje environmentálnu výchovu ako prierezovú tému, pričom dvaja uviedli v rámci možnosti iné, že realizujú environmentálnu výchovu $\mathrm{v}$ 1. ročníku na predmete Biológia ako samostatný tematický celok: Organizmus a prostredie $\mathrm{v}$ rozsahu 26 hodín a v d'alších ročníkoch sa už ENV realizuje ako prierezová téma. Odpovede väčšiny respondentov sú pochopitel'né, ked'že v súčasnosti je environmentálna výchova jednou $\mathrm{z}$ prierezových tém, ktoré sú obsahom vzdelávania podl'a štátneho vzdelávacieho programu (d’alej ŠVP). Frykova (2010) uvádza, V rámci ŠVP je environmentálna výchova vnímaná ako prostriedok, ktorý do istej miery môže ovplyvnit' environmentálne cítenie a správanie sa žiakov. Cajkova (2012) rozvíja túto problematiku o to, akú formu daná škola zvolí. Následne sa to odráža $v$ d'alších dokumentoch školy. Uvádza nezastupitel'nú úlohu koordinátora environmentálnej výchovy, ktorá má štatút poradcu vedenia školy a mimoriadne dôležitú úlohu pri začleňovaní environmentálnej výchovy do všetkých dokumentov školy.

Pri zist'ovaní odborno-metodickej pripravenosti učitel'ov na realizáciu environmentálnej výchovy iba 12,5 \% učitel'ov základných škôl odpovedalo, že sú výborne odborne i metodicky pripravení, pričom išlo o učitel'ov v základnej škole v meste. Trojštvrtinová väčšina (75\%) opýtaných odpovedala, že sú odborne i metodicky pripravení, kde $67 \%$ boli učitelia mestskej školy a $33 \%$ reprezentuje učitel'ov vidieckej školy. 12,5 \% uviedlo odpoved', že skôr nie je odborne či metodicky pripravení, pričom išlo o učitel'ov vidieckej základnej školy. V podmienkach strednej školy môžeme konštatovat', že až 60 \% respondentov hodnotí, že sú odborne i metodicky pripravení na realizáciu environmentálnej výchovy v podmienkach strednej školy zatial' čo 40 \% uviedlo, že skôr nie sú odborne a metodicky pripravení. Predpokladáme, že názor na vlastnú pripravenost’ na realizáciu environmentálnej výchovy učitel'ov zodpovedá odbornému zameraniu a kvalifikácii učitel'ov. 




\section{Obrázok 1 Odborno metodická pripravenost' učitel’ov ZŠ na realizáciu} EVV (Marinicova, 2017)

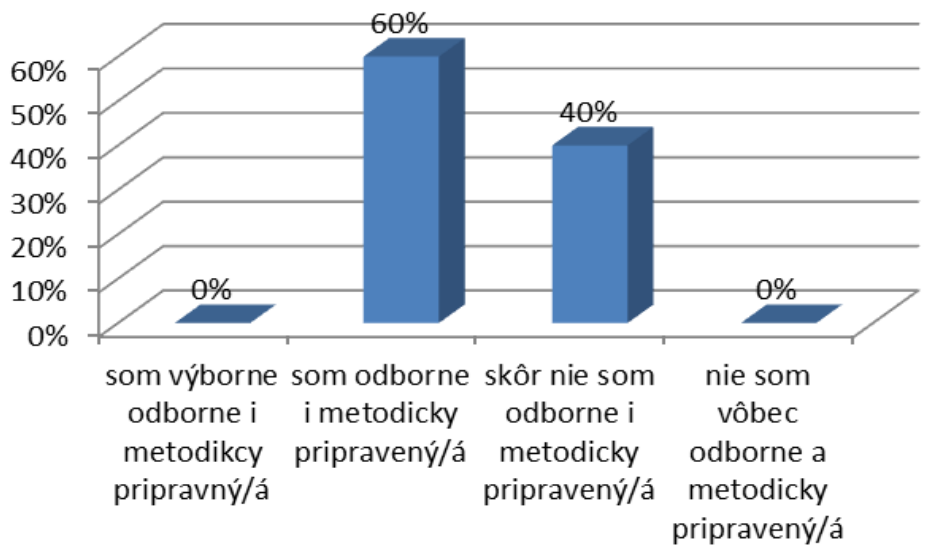

\section{Obrázok 2 Odborno metodická pripravenost' učitel’ov SOŠ na realizáciu EVV (Marinicova, 2017)}

Položka 7 dotazníka bola zameraná na zistenie akým témam sa v rámci realizácie ENV sa učitelia venujú. Vyučujúci vo vidieckej škole sa zhodli na tematike separácie odpadu, ochranu zdrojov pitnej vody a ochranu životného prostredia ako takého, ktorá zahŕn̆a ochranu biodiverzity a predchádzanie ohrozeniu endemitov. Učitelia mestskej školy uvádzajú témy spojené s odpadom - recyklácia, zhodnocovanie, potrebu klást' dôraz na ochranu ovzdušia a lesov. Ďalej sa zhodujú v potrebe ochrany prírody, zachovanie prírodných spoločenstiev a dôležitost' starostlivosti o zvieratá.

Učitelia strednej školy uviedli nasledovné témy: globálne problémy životného prostredia (znečistenie ovzdušia, vody, pôdy, odlesňovanie) a ochrana prírody a krajiny, exkurzie do zoo - životné prostredie v ubikáciách, šetriace metódy vpriemysle, pol’nohospodárstve (̌̌etrenie chemikálií, triedenie odpadov), ochrana rastlín - reziduá v potravinovom ret'azci, odborná prax pestovanie liečivých rastlín, pol'ovníctvo. Samozrejme tieto témy boli špecifickejšie v súvislosti s odborným zameraním vybranej strednej školy.

Slavonic Pedagogical Studies Journal, ISSN 1339-8660, eISSN 1339-9055, Volume 7 Issue 1, February 2018 
Zist'ovali sme aj zapájanie rodičov žiakov do environmentálnych aktivít školy. Učitelia v mestskej základnej škole uvádzajú zapojenie rodičov hlavne pri budovaní ekoučebne. Slúži na realizáciu besied a seminárov s odborníkmi, a zároveň výučbu predmetu Tvorba životného prostredia. Zároveň táto učebňa umožňuje prepojit' vyučovanie s pozorovaním, skúmaním a tvorivými aktivitami s prírodným materiálom. Učitelia vidieckej školy uvádzajú nasledovné environmentálne aktivity do ktorých zapájajú rodičov žiakov: zber bateriek a žiaroviek - dôležitost' venovat' sa tejto aktivite učitelia zdôvodňujú nasledovne. Deti aj rodičia sú vedení k triedeniu odpadu a zároveň chránia životné prostredie. Pri nesprávnej manipulácii a nakladaní s takýmto odpadom môže byt' ohrozené zdravie l'udí, organizmov ale tiež kvalitu prostredia. K podpore separácie odpadu sú rodičia aj žiaci motivovaní celoškolskou sút’ažou zberu papiera. Na základe tejto aktivity následne škola získava hygienické potreby a vybavenie pre žiakov a učitel'ov školy a zároveň najlepší žiaci sú odmeňovaní vecnými cenami. V súčasnosti má škola vytvorené biopolíčko, kde sa žiaci učia starostlivosti a hodnotám vypestovaných potravín, hlavne zelenina a bylinky. Rodičia sa aktívne zapájajú pri manuálnych a udržiavacích prácach, čo v dnešnej dobe môže vzbudit' chut' mladých l'udí, založit' si vlastnú záhradku a ocenit' kvalitné potraviny. V konečnom dôsledku to môže mat' aj následok zvyšovania kúpy ovocia a zeleniny dopestovaných na Slovensku. Škola zároveň organizuje besedy a semináre s odborníkmi z praxe v rámci rôznych svetových a slovenských dní, kde sú pozývaní aj rodičia žiakov. Môžeme konštatovat, že environmentálne aktivity v meste aj na vidieku do ktorých sú zapájaní či rodičia alebo žiaci sú na oboch školách realizované a podiel'ajú na zvyšovaní environmentálneho povedomia, na rozdiel od skúmanej strednej školy, kde $90 \%$ učitel'ov uviedlo, že nie je možné rodičov zapájat' do environmentálnych aktivit, nakol'ko je to internátna škola a žiaci sú z celého Slovenska. Prepojenie environmentálnej výchovy medzi rodičom a žiakom realizujú hlavne učitelia prostredníctvom domácich úloh, na základe ktorých ich majú s rodičmi konzultovat' a diskutovat'. Do environmentálnych aktivít sú na tejto škole zapojení predovšetkým žiaci.

Pri hodnotení materiálneho vybavenia pre efektívnu realizáciu EVV len 12,5\% učitel'ov základných škôl uviedlo, že majú výborné materiálne vybavenie (obrázok č. 2). Dostatočné materiálne vybavenie uviedlo $50 \%$ opýtaných a 37,50 \% odpovedalo, že nemajú dostatočné materiálne vybavenie na realizáciu EVV. Materiálne vybavenie v meste a na vidieku je v školách rozdielne, nakol'ko 100 \% opýtaných na vidieckej škole uviedlo, že nemajú dostatočné vybavenie. Na základe poznaného však môžeme, konštatovat', že vidiecka škola so spomínaným biopolíčkom a realizovanými aktivitami na škole má priestor realizovat' EVV. Samozrejme bolo by vhodné do budúcnosti zistit' o aké konkrétne materiálne vybavenie by mali učitelia najväčší záujem a čo by im umožnilo skvalitnit’ realizáciu EVV. 


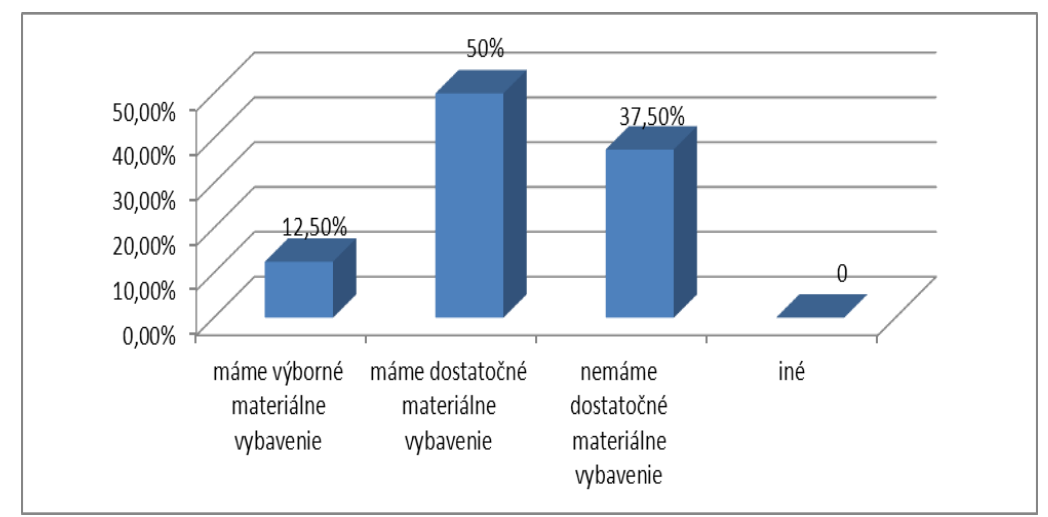

\section{Obázok 3 Hodnotenie materiálneho vybavenia na efektívnu realizáciu EVV učitel'mi základných škôl (Marinicova, 2017)}

Na základe obrázka č. 4 môžeme konštatovat', že 20 \% respondentov strednej školy uviedlo, že škola má dostatočné materiálne vybavenie na efektívnu realizáciu EVV a 80 \% uviedlo, že nemá dostatočné vybavenie na realizáciu EVV. Rovnako i v tomto prípade by bolo potrebné d'alej zistit' o aké materiálne vybavenie sa jedná.

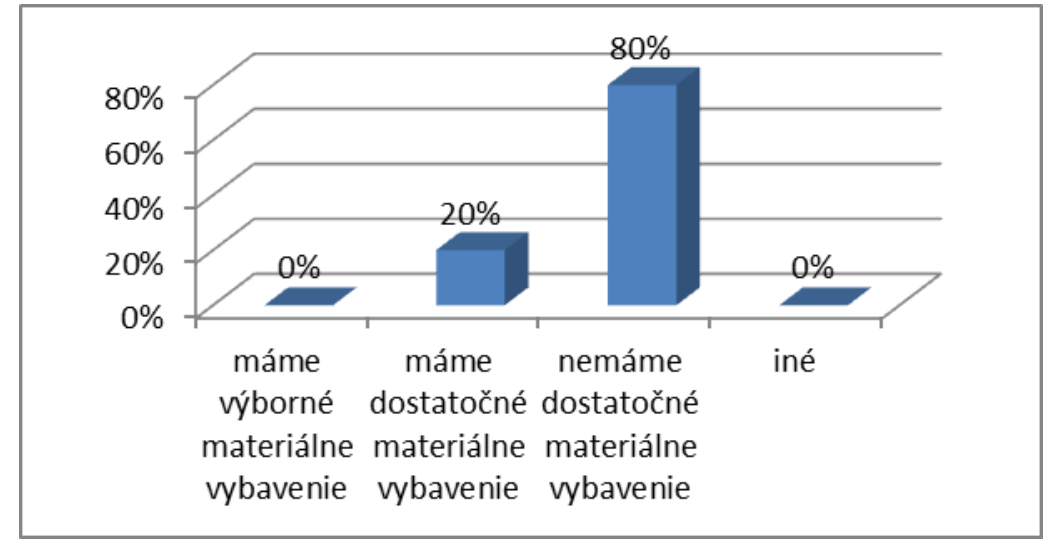

\section{Obrázok 4 Hodnotenie materiálneho vybavenia na efektívnu realizáciu EVV učitel'mi strednej školy (Marinicova, 2017)}

Posledná položka dotazníka je zameraná na konkrétne aktivity školy v rámci realizácie environmentálnej výchovy. Odpovede sa vo väčšine zhodujú s odpoved'ami položky č. 8. Vo vidieckej škole sú to hlavne zber papiera, žiaroviek a bateriek, triedenie odpadu, práca na biopoli, výsadba ihličnatých stromov, monitoring výskytu netopierov v obci. Podobné aktivity sa realizujú aj v mestskej škole: triedenie odpadu, čistenie studničiek, výrobky v tvorivých dielñach, ktoré sú vyrobené výlučne z prírodných materiálov, deň stromu, deň zvierat, aktivity v ekoučebni - sejba a pestovanie zeleniny.

$\mathrm{Na}$ strednej škole respondenti uviedli predovšetkým aktivity ktoré sú priamo spojené s vyučovacím procesom a predmetom, ktorý vyučujú. Sú to 
nasledovné aktivity: ekologické vychádzky do prírodných rezervácii a exkurzie, čistenie okolia školy, rozmiestnenie zberných nádob na smeti $v$ škole a v areáli školy, premietanie DVD s enviro problematikou, besedy s pracovníkmi štátnej ochrany prírody a v krajskej knižnici, prezentácie žiakov na vybrané témy, šetrenie chemikálií na laboratórnych cvičeniach, použivanie digestora.

\section{Záver}

Aj napriek tomu, že si uvedomujeme vel'mi nízku reprezentatívnost' výskumného súboru, naše skúmanie bolo aspoň malou sondou do problematiky, ktorej aktuálnost' a naliehavost' d’alšieho riešenia je významná. Výsledky dotazníkového prieskumu ukázali, že skúmané základné školy aj stredná škola sa významne podielajú na realizácii environmentálnej výchovy žiakov, čo je v súlade aj so Štátnym vzdelávacím programom. Podl’a názoru respondentov má významný podiel na získavaní environmentálnych poznatkov a formovaní environmentálnych postojov a správania žiakov mladšieho a staršieho školského veku environmentálna výchova, ktorá vedie človeka k pochopeniu vzt'ahov medzi organizmami a učí človeka, aby si vytvoril vzt’ah k životnému prostrediu a poskytuje informácie, ktoré vedú $\mathrm{k}$ premyslenej a ciel'avedomej ochrane životného prostredia. Záverom môžeme konštatovat', že opytovaní učitelia považujú za vel'mi dôležité realizovat' environmentálnu výchovu. Za najaktuálnejšie témy považujú separáciu a recykláciu odpadu a ochranu životného prostredia, ktorá zahŕňa ochranu lesov, ovzdušia a zdrojov pitnej vody. Učitelia sa snažia čo najviac implementovat' environmentálnu výchovu do vyučovacieho procesu rôznymi formami: exkurzie, besedy, odborné prednášky s expertmi z praxe, domáce úlohy, práca na vlastných políčkach v prostredí základných škôl alebo triedenie odpadu, prípadne d'alšie aktivity.

Zistili sme aj rozdiely medzi realizáciou environmentálnej výchovy na základných školách a strednej odbornej škole. Konštatujeme, že vo vidieckej a malej mestskej základnej škole učitelia prezentovali, že ich škola je environmentálne zameraná, zatial čo na strednej škole je environmentálna výchova realizovaná hlavne ako prierezová téma. Na skúmaných základných školách sú na rozdiel od strednej školy zapájaní aj rodičia žiakov do realizovaných aktivít. Na strednej škole žiadni z učitel'ov neabsolvoval za posledných 5 rokov vzdelávanie zamerané na problematiku EVV. Iba dvaja učitelia základných škôl absolvovali vzdelávanie $\mathrm{v}$ rámci neziskových organizácií. Zo zisteného môžeme zhrnút' aj v súlade s Rezortnou koncepciou environmentálnej výchovy (2015), že komplexnejšie k problematike pristupujú naozaj tie školy, ktoré prezentujú environmentálne zameranie a ciele vo svojich školských vzdelávacích programoch a boli hlavne zapojené do projektov dlhodobého charakteru. Môžeme predpokladat' aj to, že je jednoduchšie realizovat' environmentálne aktivity na nižšom stupni vzdelávania, kde je viac možností uplatňovat' zážitkové a aktivizujúce metódy vzdelávania.

Môžeme konštatovat' $\mathrm{z}$ výpovedí respondentov aj rozdiely $\mathrm{v}$ materiálnom vybavení škôl pre realizáciu environmentálnej výchovy, kde učitelia mestskej základnej školy uvádzajú dostatočné až výborné vybavenie, zatial' čo učitelia 
vidieckej školy uviedli, že ich vybavenie na efektívnu realizáciu EVV nie je dostatočné. Rovnako aj na strednej odbornej škole sme zistili, že väčšina učitel'ov $(80 \%)$ uviedla nedostatočné materiálne vybavenie na realizáciu environmentálnej výchovy aj napriek tomu, že ide o strednú odbornú školu pol'nohospodárskeho zamerania. Bolo by do budúcnosti žiaduce zistit' o aké materiálne vybavenie sa jedná, aby bolo možné analyzovat' nástroje na zabezpečenie adekvátneho materiálneho vybavenia na daných školách.

Na základe teoretického štúdia problematiky i na základe našich zistení odporúčame:

- zvyšovat' motiváciu učitel'ov pre realizovanie environmentálnej výchovy a výchovy $\mathrm{k}$ TUR rôznymi formami (napr. do Zákona o pedagogických zamestnancoch presadit' systémový prístup $\mathrm{k}$ zaradeniu odmeny pre koordinátorov),

- vyčlenit' investície do d'alšieho vzdelávania pedagogických pracovníkov koordinácia environmentálnej výchovy (resp. výchovy k TUR),

- realizovat premyslený a reprezentatívny výskum účinnosti environmentálnej výchovy a vzdelávania $\mathrm{v}$ základných a stredných školách SR so zameraním na dosahované ciele, realizovaný obsah, používané výchovno-vzdelávacie formy a metódy apod.,

- zapracovat' filozofiu TUR do Štátneho vzdelávacieho programu pre všetky vzdelávacie úrovne,

- využívat' odborný potenciál neziskových organizácií a d'alších inštitúcií v spolupráci so školami (napr. pri zvyšovaní vedomostí či už učitel'ov alebo žiakov odporúčame využívat' ponuky organizácií, ktoré sa aktívne venujú environmentálnej výchove, napr.: Živica, Strom života, Slovenská agentúra životného prostredia, Špirála, či d'alšie),

- rozšírit' možnosti zapojenia škôl do environmentálnych programov a všestranne podporovat' tvorivost' žiakov a učitel'ov v tejto oblasti.

\section{Bibliographic references}

BIEDENWEG, K. et al. 2013. The History and Promise of Environmental Education. In Across the Spectrum: Resources for Environmental Education [online]. Florida: North American Association for Environmental Education, 2013. [cit. 2015-01-22]. Available online: http://www.naaee.net/sites/default/files/publications/eebook/EEebook_downl oad.pdf

CAJKOVA, G. 2012. Prakticka environmentalna vychova I [online]. Bratislava : Metodicko-pedagogicke centrum, 2012. [cit. 2016-2-5]. Available $\quad$ online: http://mpcedu.sk/shared/Web/OPSOSO\%20II.\%20kolo\%20vyzvy\%20na\%20poziciu\% 20Odborny\%20poradca\%20vo\%20vzdelavani/OPS_Cajkova\%20Galina\%20 \%20Prakticka\%20environmentalna\%20vychova\%20I..pdf

FRYKOVA, E. 2010. Environmentalna vychova vo vyucovacom procese. Bratislava: Metodicko-pedagogicke centrum v Bratislave, 2010, s. 56, ISBN 978-80-8052-348-0

HILBERT, H. 2007a. Sucasny stav perspektivy vzdelania v oblasti TUR na Slovensku [online]. In Ekologia a Environmentalistika. Zvolen: TUZVO, 36 
- $48 \quad$ s. $\quad$ [cit. 4.10.2016]. Available online: https://www.tuzvo.sk/files/FEE/dekanat_fee/5_hilbert_AFE.pdf

HILBERT, H. 2007b. Implementacia vychovy a vzdelavania k trvalo udrzatelnemu rozvoju na narodnej urovni. In Enviromagazin 12, mimoriadne cislo, 2007. 4-5 s.

HIPS, J. 2004. Ako je to s peniazmi na environmentalnu vychovu. In Dalekohlad, roc. 1, cislo 1, 2004, 3 s. ISSN 1336-4642.

HIPS, J. 2005. Neucme o gulatych stvorcoch. In Dalekohlad, rocnik 2, cislo 4, 2005, ISSN 1336-4642

HORKA, H. 2005. Ekologicka dimenze vychovy a vzdelavani ve skole 21. stoleti. Brno: Masarykova univerzita, 2005. ISBN 80-210-3750-4.

IZAKOVICOVA, Z. 2010. Nove netradicne formy environmentalnej vychovy [online]. [cit. 2016 - 10- 4]. In Geographia Cassoviensis, roc. IV, cislo 2, 2010, Available online: http://geografia.science.upjs.sk/images/geographia_cassoviensis/articles/GC2010-42/04Izakovicova.pdf

KANCIR, J. - SUCHA, I. 2012. Environmentalna vychova u nas a v zahranici - analyza sucasneho stavu realizacie. In Komplexnost a integrita $\mathrm{v}$ predprimarnej, primarnej a specialnej edukacii. Zbornik $\mathrm{z}$ vedeckej konferencie s medzinarodnou ucastou. Presov: Vydavatelstvo Presovskej univerzity v Presove, 2012. ISBN 978-80-555-0664-7. CD-ROM, s. 261-267

KOLOCANY, F. 2006. Akcny plan trvalo udrzatelneho rozvoja $2005-2010$ [online]. [cit. 2016 - 10- 4]. In Enviromagazin, vol. 2. 2006, s. 4 -5. Available online: http://www.enviromagazin.sk/enviro2006/enviro2/03.pdf KOLSOVSKA, J. 2009. Moznosti vyuzitia foriem a metod prace v zaujmovom utvare $\mathrm{s}$ environmentalnym zameranim na I. stupni ZS. Bratislava: Metodicko-pedagogicke centrum, Regionalne pracovisko Presov. $63 \mathrm{~s}$.

KOPP, J. 2008. Prurezova environmentalni vychova: globalni nebo regionalni pristup? In Environmentalni vychova jako prurezove tema. Plzen: Zapadoceska univerzita, 2008. s. 19-26. ISBN 978-80-7042-757-5.

MARINICOVA P. 2017. Ekologicka a environmentalna vychova ako sucast vychovy k trvalo udrzatelnemu rozvoju. Zaverecna praca. Skolitel: PaedDr. Timea Seben Zatkova, PhD., Nitra: SPU, 58 s.

MARTISOVA, E. 2012. Netradicne formy rozvoja environmentalneho poznania a citenia deti [online]. MPC Bratislava. [cit. 2016 - 10 - 4]. Available online: http://mpcedu.sk/shared/Web/OPSOSO\%20II.\%20kolo\%20vyzvy\%20na\%20poziciu\% 20Odborny\%20poradca\%20vo\%20vzdelavani/OPS_\%20Martisova\%20Erika $\% 20 \% 20$ Netradicne $\% 20$ formy $\% 20$ rozvoja $\% 20$ environmentalneho $\% 20$ pozna nia\%20a\%20citenia\%20deti.pdf

Narodna strategia trvalo udrzatelneho rozvoja SR schvalena uznesenim vlady SR c. 978/2001 [online]. [cit. 2016- 10-3]. Dostupne na internete: http://www.minzp.sk/dokumenty/strategicke-dokumenty/.

MINISTERSTVO ZIVOTNEHO PROSTEDIA SLOVENSKEJ REPUBLIKY, 2004. Environmentalna vychova v posobnosti MZP SR a jeho rezortnych organizaciach [online]. [cit. 2016 - 10- 4]. Available online:www.minzp.sk/files/o-nas/veda-vychova...vychova/envi-vychova.doc 
NANISTOVA, E. - MESAROSOVA, B. 1993. Ekologia cloveka. In Ekologicka vychova. 1. vyd. Zvolen: Ustav pre vychovu a vzdelavanie pracovnikov lesneho a vodneho hospodarstva Slovenskej republiky, 1933. ISBN 80-88677-03-3, s. 27-58.

NOVE TRENDY V EKOLOGII [online]. 2000. Presov. Katedra ekologie a biologie FHPV PU, 2000. [cit. 2016 - 10- 4]. Available online:http://www.fhpv.unipo.sk/PU/FHPV/Ekologia/trendy.htm

PAGAC, J. 1993. Zasady, obsah, formy a metody environmentalnej vychovy. In Ekologicka vychova. 1. vyd. Zvolen: Ustav pre vychovu a vzdelavanie pracovnikov lesneho a vodneho hospodarstva Slovenskej republiky, 1993. ISNB 80-88677-03-3, s. 93-117.

ROS, J. 2004. Dalekohlad, rocnik 1, cislo 3, 2004, 12 s. ISSN 1336-4642.

Rezortna koncepcia environmentalnej vychovy, vzdelavania a osvety do roku 2025. 2015. [online]. [cit. 2017 - 10- 27]. Available online: http://www.sazp.sk/app/cmsFile.php?disposition=i\&ID=59

STEVENSON, R. et al., 2013. International Handbook of Research on Environmental Education. New York: AERA, 2013. 529 p. ISBN 978-0-20381333-1.

STRATEGIE EUROPSKEJ HOSPODARSKEJ KOMISIE OSN PRE VYCHOVU K TRVALO UDRZATELNEMU ROZVOJU. 2007. Strategie europskej hospodarskej komisie OSN pre vychovu k trvalo udrzatelnemu rozvoju [online]. [cit. 2016 - 10- 4]. In Priloha Enviromagazinu. Vol. 2. 2007. 1- 5 s.

SUCHA, I. 2014. Aktualny stav mimoskolskej environmentalnej vychovy na Slovensku [online]. [cit. 2016 - 10- 4]. In Prohuman. Available online: http://www.prohuman.sk/pedagogika/aktualny-stav-mimoskolskejenvironmentalnej-vychovy-na-slovensku

SIMONOVICOVA, J. - KOSKOVA, K. 2011. Ekologicka stopa- vychova k trvalo udrzatelnemu rozvoju. Treningovy manual pre ucitelov. Vyd: SAZP Banska Bystrica, $124 \mathrm{~s}$.

TOMA, P. 2001. Problematika trvalo udrzatelneho rozvoja a Slovenska republika [online] [cit. 2016 - 10- 6]. Bratislava: MZP SR, 2001. Available online:

http://www.tur.sk/index.stm?apc=079efcdc8d3c1e81704b24af08cdc6376$11 \& \mathrm{x}=72642$

VINCIKOVA, S. 1998. Teoria a prax environmentalnej vychovy. B. Bystrica: Dali, 1998. ISBN 8096789325.

Zakon o zivotnom prostredi c. 17/1992 Zb. [online]. [cit. 2016 - 10- 6]. Dostupne na internete: http://www.zakonypreludi.sk/zz/1992-17

ZEDGINIDZE, G. - CHANTURIA, R. - SIPRASHVILI, T. 2012. From Tbilisi to Tbilisi+35: History of Education for Sustainable Development [online]. [cit. 2016 - 10- 6]. Tbilisi: Ministry of Environment Protection of Georgia, 2012. 26 p. Available online: <https://docs.google.com/file/d/0BwRArdItyCFtY2w1NFZ6clFEZ0E/edit?pl $\mathrm{i}=1>$.

5. narodna konferencia $\mathrm{s}$ medzinarodnou ucastou Vychova a vzdelavanie $\mathrm{k}$ trvalo udrzatelnemu rozvoju, 2009. [online]. Banska Bystrica: UMB. [cit. 
2017-09-09]. Available online: http://www.spirala.sk/wpcontent/uploads/100201-zavery-konferencie-tur.pdf

PaedDr.Tímea Šeben Zat'ková, PhD.

Centrum pedagogiky a psychologického poradenstva FEM SPU v Nitre

Nitra

Slovakia

timea.zatkova@uniag.sk 